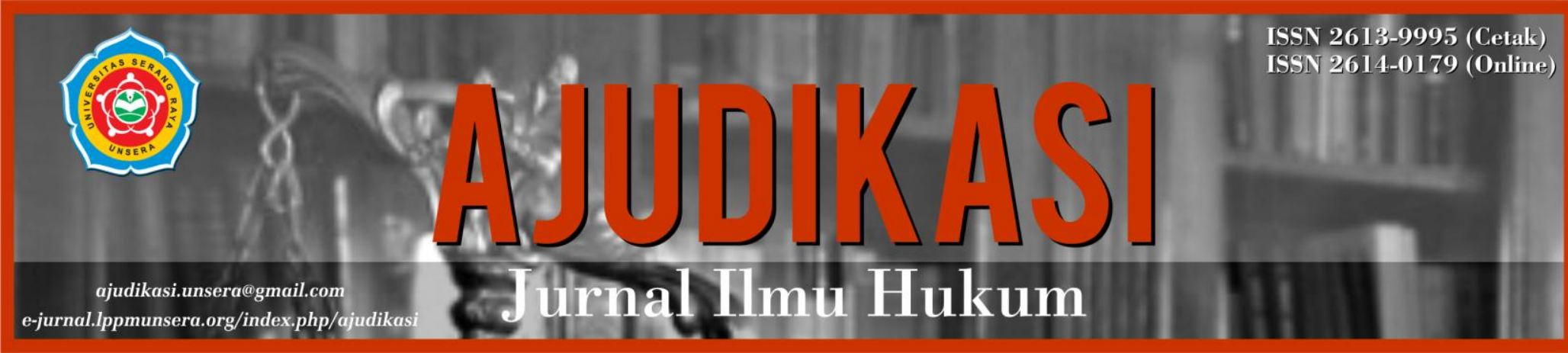

\title{
KAJIAN TERHADAP HAK EKSKLUSIF ATAS JINGLE DARI PERSPEKTIF HAK CIPTA DAN MEREK
}

\author{
${ }^{1}$ Hosiana Daniel Adrian Gultom, ${ }^{2}$ Ellora Sukardi, ${ }^{3}$ Serlly Waileruny \\ Fakultas Hukum, Universitas Pelita Harapan, Tangerang, Banten. \\ Correspondent email : hosiana.gultom@uph.edu
}

\begin{tabular}{|lll}
$\mid$ Article History & $:$ & \\
$\mid$ | Submission & $:$ & 29 Oktober 2021 \\
| Last Revissions & $:$ & 13 Desember 2021 \\
|Accepted & $:$ & 20 Desember 2021 \\
| Copyedits Approved & $:$ & 21 Desember 2021
\end{tabular}

\begin{abstract}
As an integral part in the category of creation in the form of songs or music in the copyright law system, jingle is also a sign of trade in the form of sound which is a type of sound mark in the trademark law system. This is a good thing because jingles are protected by copyright and trademark laws. Copyright law protection uses a declarative system while trademark law uses a constitutive system. In the copyright and trademark legal system there are exclusive rights, namely rights granted by the state to the rightful owner. There are two types of exclusive rights in copyright, namely moral rights and economic rights, while exclusive rights in trademarks are called trademark rights. With the existence of moral rights and economic rights in the copyright law system and trademark rights in the trademark legal system, various benefits arise from the ownership of jingles. Through a study of moral rights and economic rights in Law Number 28 of 2014 concerning Copyright and trademark rights in Law Number 20 of 2016 concerning Marks and Geographical Indications, it is hoped that jingle owners can understand copyright law and trademark law related to jingles. as well as the various benefits of the jingle.
\end{abstract}

Keywords: Copyright; Trademarks; Economic Rights; Moral Rights; Jingle. 


\section{A. PENDAHULUAN}

Dalam dunia periklanan dikenal istilah kata jingle. Perlu diketahui bahwa jingle berbeda dengan lagu $^{1}$ maupun musik. Lagu (nyanyian) merupakan hasil karya seni hubungan dari seni suara dan seni bahasa, sebagai karya seni suara melibatkan melodi dan warna suara penyanyi. ${ }^{2}$ Musik adalah bentuk suatu hasil karya seni bunyi dalam bentuk lagu atau komposisi musik yang mengungkapkan pikiran dan perasaan penciptanya melalui unsur-unsur musik yaitu irama melodi, harmoni, bentuk dan struktur lagu dan ekspresi sebagai satu kesatuan. ${ }^{3}$ Jingle adalah alat yang membuat orang terpesona oleh pesan penjualan dan membentuk identitas dengan menyusunnya ke dalam nada yang menarik perhatian, yang dapat dinyanyikan. ${ }^{4}$ Jingle adalah slogan iklan yang dibuat menjadi musik. ${ }^{5}$

Dari pengertian jingle tersebut diatas maka dalam jingle terdapat nada yang dirangkai menjadi musik dan seringkali musik tersebut ditambah dengan nyanyian sehingga menjadi lagu. Dengan adanya musik dan lagu dalam jingle maka jingle merupakan seni. Bagian menimbang huruf a Undang-Undang Nomor 28 Tahun 2014 tentang Hak Cipta (UU Hak Cipta) memberikan penegasan bahwa hak cipta merupakan kekayaan intelektual di bidang ilmu pengetahuan, seni, dan sastra yang mempunyai peranan strategis dalam mendukung pembangunan bangsa dan memajukan kesejahteraan umum sebagaimana diamanatkan oleh Undang-Undang Dasar Negara Republik Indonesia.

Pasal 40 ayat 1 huruf d UU Hak Cipta mengatur bahwa lagu maupun musik, baik yang disertai dengan teks atau tidak disertai teks, dalam arti karya cipta yang utuh, merupakan seni sebagai objek hak cipta, sehingga terhadapnya diberikan perlindungan hak cipta. Kemudian Pasal 1 angka 3 UU Hak Cipta memberikan pengertian bahwa ciptaan adalah setiap hasil karya cipta di bidang ilmu pengetahuan, seni, dan sastra yang dihasilkan atas inspirasi, kemampuan, pikiran, imajinasi, kecekatan, keterampilan, atau keahlian yang diekspresikan dalam bentuk nyata.

Berdasarkan ketentuan Pasal 40 ayat 1 huruf d dan Pasal 1 angka 3 UU Hak Cipta maka jingle termasuk dalam objek ciptaan dalam bidang seni sehingga jingle mendapatkan pelindungan hukum hak cipta. Definisi hak cipta diatur dalam Pasal 1 angka 1 UU Hak Cipta, yaitu hak eksklusif pencipta yang timbul secara otomatis berdasarkan prinsip deklaratif setelah suatu ciptaan diwujudkan dalam bentuk nyata tanpa mengurangi pembatasan sesuai dengan ketentuan peraturan perundang-undangan.

\footnotetext{
1 Mozza Pratidina, "Konsepsi Dan Implementasi Perlindungan Hukum Bagi Jingle Sebagai Merek Nontradisional Suara" (Universitas Pelita Harapan, 2020).

${ }^{2}$ Roma Ayuni A. Loebis, "Lagu, Kaum Muda Dan Budaya Demokrasi," Pustaka 8, no. 2 (2018): 82.

${ }^{3}$ Niswati Khoiriyah and Syahrul Syah Sinaga, "Pemanfaatan Pemutaran Musik Terhadap Psikologis Pasien Pada Klinik Ellena Skin Care Di Kota Surakarta,” Jurlan Seni Musik 6, no. 2 (2017): 82.

${ }^{4}$ Moech Nasir, "Analisis Pengaruh Bintang Iklan Dan Jingle Iklan Terhadap Daya Ingat Konsumen Produk "Vaseline Men"," in Prosiding Seminar Nasional Ekonomi Dan Bisnis \& Call for Paper FEB UMSIDA (Surakarta, 2016).

${ }^{5}$ Rajulur Rahman, "Suara Sebagai Merek Yang Dilindungi Berdasarkan Undang-Undang Nomor 20 Tahun 2016 Tentang Merek Dan Indikasi Geografis" (Universitas Indonesia, 2018).
} 
Hak eksklusif adalah hak yang hanya diperuntukkan bagi pencipta, sehingga tidak ada pihak lain yang dapat memanfaatkan hak tersebut tanpa izin pencipta. ${ }^{6}$ Hak eksklusif yang diberikan kepada pencipta merupakan suatu bentuk penghargaan atas usaha si pencipta dalam menghasilkan suatu karya. ${ }^{7}$ Pasal 4 UU Hak Cipta menyatakan bahwa hak eksklusif pada hak cipta terdiri dari dua macam hak, yaitu hak moral dan hak ekonomi. Kemudian Pasal 1 angka 2 UU Hak Cipta memberikan definisi pencipta, yaitu seorang atau beberapa orang yang secara sendiri-sendiri atau bersama-sama menghasilkan suatu ciptaan yang bersifat khas dan pribadi.

Sedangkan prinsip deklaratif adalah suatu sistem yang tidak mengharuskan adanya pencatatan (istilah pencatatan sama dengan istilah pendaftaran pada undangundang hak cipta terdahulu). ${ }^{8}$ Dengan kata lain walaupun pencipta tidak mencatatkan ciptaannya, tetapi pencipta tetap memiliki perlindungan langsung ketika ciptaan selesai dibuat, yakni berupa hak untuk mengontrol agar tidak ada seorang pun yang memanfaatkan haknya tanpa seizin pencipta. ${ }^{9}$

Jingle banyak dipergunakan oleh pemiliknya untuk memasarkan dan mengiklankan barang dan/atau jasa yang dikemas sedemikian rupa dan menggunakan komposisi musik dan lirik, serta seringkali menyebutkan merek yang diiklankan. Dalam jingle terkadang terkandung lirik mengenai produk tersebut ataupun hal yang berkaitan dengan produk yang diiklankan. ${ }^{10}$ Pada umumnya, jingle merupakan pengulangan nama suatu brand dan slogan dengan ritme tertentu dengan durasi yang cukup singkat. ${ }^{11}$

Jingle dipergunakan dalam iklan sebagai alat promosi produk barang maupun jasa, yang terhadapnya disematkan suatu merek, dengan tujuan agar produk dan merek tersebut dapat diketahui oleh konsumen. Melalui jingle yang dikemas secara singkat dan menarik, maka pengiklan berharap dapat memberikan kesan terhadap konsumen, sehingga kemudian konsumen tertarik dan membeli produk maupun jasa yang diiklankan dalam jingle tersebut. Dari segi durasi jingle, walaupun tidak ada aturan yang baku, namun jingle iklan lazimnya berdurasi sekitar beberapa puluh detik sampai sekitar tiga menit.

Suara menjadi tanda pembeda yang potensial untuk didaftarkan, terutama pada merek khusus yang memiliki tanda khas suara yang bernilai ekonomi tinggi. ${ }^{12}$ Melihat penggunaan jingle dalam kegiatan pemasaran dan periklanan barang dan/atau jasa, maka jingle dapat diberikan pelindungan hak atas merek sebagai tipe merek suara. Merek suara

\footnotetext{
${ }^{6}$ Inda Nurdahniar, "Analisis Penerapan Prinsip Perlindungan Langsung Dalam Penyelenggaraan Pencatatan Ciptaan," Veritas Et Justitia 2, no. 1 (2016): 233-234.

7 Kemala Megahayati, Muhammad Amirulloh, dan Helitha Novianty Muchtar, "Perlindungan Hukum Sinematografi Terhadap Pengaksesan Tanpa Hak Oleh Pengguna Aplikasi Telegram Berdasarkan UndangUndang Hak Cipta Dan Undang-Undang Informasi Dan Transaksi Elektronik Di Indonesia," Ajudikasi: Jurnal Ilmu Hukum 5, no. 1 (2021): 5.

${ }^{8}$ Nurdahniar Op.Cit. hlm. 234

${ }^{9}$ Ibid.

${ }^{10}$ Ibid.5

${ }^{11}$ Pratidina Op.Cit,. hlm. 234.

12 Ni Putu Wanda Pramesti Dewi, "Pendaftaran Suara Sebagai Merek Non Tradisional Berdasarkan UndangUndang No. 20 Tahun 2016 Tentang Merek," Ilmu Hukum 7, no. 10 (2019): 3.
} 
merupakan tipe merek baru yang masuk dalam kategori merek nontradisional dan telah diatur dalam Undang-Undang Nomor 20 Tahun 2016 tentang Merek dan Indikasi Geografis (UU Merek dan IG). Dalam UU Merek dan IG diberikan pengaturan berbagai tipe merek nontradisional, salah satunya adalah merek suara.

Secara normatif, merek didefinisikan sebagai sebuah tanda yang dapat membedakan barang dan jasa yang diproduksi oleh suatu perusahaan terhadap perusahaan lainnya. ${ }^{13}$ Pasal 1 angka 1 UU Merek dan IG memberikan definisi merek sebagai tanda yang dapat ditampilkan secara grafis berupa gambar, logo, nama, kata, huruf, angka, susunan warna, dalam bentuk dua dimensi dan/atau tiga dimensi, suara, hologram, atau kombinasi dari dua atau lebih unsur tersebut untuk membedakan barang dan/atau jasa yang diproduksi oleh orang atau badan hukum dalam kegiatan perdagangan barang dan/atau jasa. Dari definisi tersebut dapat diketahui 3 (tiga) unsur pokok dalam merek yaitu berupa tanda, memiliki daya pembeda, digunakan dapam perdagangan barang dan/atau jasa. ${ }^{14}$

Berdasarkan penggunaannya merek dikategorikan sebagai merek dagang dan merek jasa. Pasal 1 angka 2 UU Merek dan IG memberikan definisi merek dagang sebagai merek yang digunakan pada barang yang diperdagangkan oleh seseorang atau beberapa orang secara bersama-sama atau badan hukum untuk membedakannya dengan barang sejenis lainnya. Kemudian Pasal 1 angka 3 UU Merek dan IG memberikan definisi merek jasa sebagai merek yang digunakan pada jasa yang diperdagangkan oleh seseorang atau beberapa orang secara bersama-sama atau badan hukum untuk membedakannya dengan jasa sejenis lainnya. Melihat penggunaan jingle dalam pemasaran dan periklanan barang maupun jasa dan definisi merek yang memasukkan suara sebagai merek, maka jingle memenuhi syarat sebagai merek suara.

Supaya dapat diberikan pelindungan hukum berupa hak atas merek maka suatu merek harus terlebih dahulu terdaftar. Ini adalah prinsip konstitutif dalam sistem hukum merek dimana pelindungan hukum merek tidak otomatis muncul, melainkan perlu ada upaya permohonan pendaftaran merek oleh pemilik merek ke pemerintah dan melalui berbagai tahapan sampai merek tersebut terdaftar. Permohonan ini harus diajukan dengan iktikad baik (good faith). ${ }^{15}$ Dengan telah terdaftarnya merek maka timbul pelindungan hukum merek. Singkat kata dapat dikatakan bahwa hak atas merek diperoleh setelah merek terdaftar di pemerintah.

Berdasarkan seluruh uraian diatas maka dapat dipahami bahwa jingle memenuhi syarat untuk mendapat pelindungan hukum hak cipta dan merek karena jingle merupakan ciptaan lagu atau musik dan dipergunakan dalam mengiklankan barang dan/atau jasa. Yang pasti jingle saat ini memperoleh perlindungan ganda yaitu dapat dilindungi secara otomatis dan dicatatkan sebagai hak cipta dan sekaligus dapat didaftarkan juga sebagai

\footnotetext{
${ }^{13}$ Henry Soelistyo, Badfaith Dalam Hukum Merek (Yogyakarta: Maharsa, 2016).

14 Ranti Fauza; Santika Tisni Mayana, Hukum Merek Perkembangan Aktual Perlindungan Merek Dalam Konteks Ekonomi Kreatif Di Era Disrupsi Digital (Bandung: Refika Aditama, 2021).

15 Rahmi Jened, Hukum Merek (Trademark Law) Dalam Era Globalisasi Dan Integrasi Ekonomi, Pertama (Jakarta: Kencana, 2015).
} 
merek. ${ }^{16}$ Dengan adanya pelindungan ganda terhadap jingle, maka jingle mendapatkan dua hak eksklusif, yaitu hak eksklusif dalam bentuk hak moral dan hak ekonomi yang didapat dari sistem pelindungan hukum hak cipta, dan hak eksklusif berupa hak atas merek yang didapat dari sistem pelindungan hukum merek. Berdasarkan hal tersebut penulis bermaksud mengkaji dua hak eksklusif yang didapat oleh jingle dengan mengajukan dua rumusan masalah sebagai berikut: Pertama, bagaimana pengaturan hak moral dan hak ekonomi dalam UU Hak Cipta yang terkait dengan jingle. Kedua, bagaimana pengaturan hak atas merek dalam UU Merek dan IG yang terkait dengan jingle.

\section{B. METODE PENELITIAN}

Dalam penelitian ini, metode pendekatan yang dipergunakan adalah metode yuridis normatif. Penulis melakukan kajian terhadap hak eksklusif berupa hak moral dan hak ekonomi yang diatur dalam Undang-Undang Nomor 28 Tahun 2014 tentang Hak Cipta dan hak eksklusif berupa hak atas merek yang diatur dalam Undang-Undang Nomor 20 Tahun 2016 tentang Merek dan Indikasi Geografis. Penelitian dilakukan secara deskriptif analisis, yaitu penelitian dengan menggambarkan kenyataan yang ada dan kemudian melakukan kajian pengaturannya dalam undang-undang untuk mencapai pemahaman yang utuh dan komprehensif. Teknik pengumpulan data dilakukan melalui studi kepustakaan yaitu mengumpulkan berbagai materi dengan cara membaca peraturan perundang-undangan, buku-buku, jurnal ilmiah, dan sumber kepustakaan lainnya. Kemudian berbagai data tersebut penulis kaji secara kualitatif.

\section{HASIL DAN PEMBAHASAN}

\section{Pengaturan Hak Moral dan Hak Ekonomi Dalam Undang-Undang Hak Cipta Yang Terkait Dengan Jingle}

Telah diuraikan dalam bagian latar belakang bahwa dalam konteks hak cipta, yang dimaksud dengan hak eksklusif adalah hak yang diperuntukkan bagi pencipta. Hak eksklusif dimaknai sebagai bentuk penghargaan atas usaha pencipta dalam menghasilkan suatu karya dalam lapangan ilmu pengetahuan, seni, dan sastra. Hak eksklusif pada hak cipta lahir pada saat suatu ciptaan telah selesai diciptakan dan berwujud nyata. Hak moral dan hak ekonomi merupakan dua hal yang saling berdampingan. ${ }^{17}$

Berbicara mengenai hak moral itu sendiri, hak moral adalah hak yang melekat pada diri pencipta atau pelaku yang tidak dapat dihilangkan atau dihapus dengan alasan apapun walaupun hak cipta atau hak terkait telah dialihkan. ${ }^{18}$ Hak moral tidak dapat dialihkan selama pencipta tersebut masih hidup, tetapi pelaksanaannya dapat

\footnotetext{
${ }^{16}$ Ibid., hlm. 124.

${ }^{17}$ R. Diah Imaningrum Susanti, Hak Cipta Kajian Filosofis Dan Historis, 2017.

${ }^{18}$ Tim Visi Yustisia, Panduan Resmi Hak Cipta Dari Mendaftar, Melindungi, Hingga Menyelesaikan Sengketa , 2015.
} 
dialihkan dengan wasiat atau sebab lain sesuai dengan peraturan perundang-undangan setelah penciptanya meninggal dunia. ${ }^{19}$

Hak Moral adalah hak yang bersifat manunggal antara ciptaan dan diri pencipta, atau dapat juga dikatakan integritas dari si pencipta. ${ }^{20}$ Mengingat esensi hak moral itu bersifat personal atau pribadi dan melekat pada diri pencipta, maka hak moral tampil mandiri dan terpisah dari hak ekonomi atas ciptaan. ${ }^{21}$ Pasal 5 UU Hak Cipta menegaskan bahwa hak moral merupakan hak yang melekat secara abadi pada diri pencipta untuk:

a. mencantumkan atau tidak mencantumkan namanya pada salinan sehubungan dengan pemakaian ciptaannya untuk umum

b. menggunakan nama alias atau samaran

c. mengubah ciptaannya sesuai dengan kepatutan dalam masyarakat

d. mengubah judul dan anak judul ciptaan

e. mempertahankan haknya dalam hal terjadi distorsi ciptaan, mutilasi ciptaan, modifikasi ciptaan, atau hal yang bersifat merugikan kehormatan diri atau reputasinya.

Penjelasan Pasal 5 huruf e UU Hak Cipta memberikan pemahaman bahwa yang dimaksud dengan distorsi ciptaan adalah tindakan pemutarbalikan suatu fakta atau identitas ciptaan. Mutilasi ciptaan adalah proses atau tindakan menghilangkan sebagian ciptaan. Kemudian modifikasi ciptaan adalah pengubahan ciptaan. Dengan demikian pencipta memiliki hak untuk melakukan upaya hukum terhadap pihak yang melakukan perbuatan terlarang atas ciptaan. Selanjutnya berbicara mengenai hak ekonomi. Pasal 8 UU Hak Cipta mengartikan hak ekonomi sebagai hak eksklusif pencipta atau pemegang hak cipta untuk mendapatkan manfaat ekonomi atas ciptaan. Pasal 1 angka 4 UU Hak Cipta memberikan pengertian bahwa pemegang hak cipta adalah pencipta sebagai pemilik hak cipta, pihak yang menerima hak tersebut secara sah dari pencipta, atau pihak lain yang menerima lebih lanjut hak dari pihak yang menerima hak tersebut secara sah.

Adapun pencipta atau pemegang hak cipta memiliki hak ekonomi yang diatur dalam Pasal 9 UU Hak Cipta. Kegiatan yang dapat dilakukan oleh pemegang hak ekonomi ialah: penerbitan ciptaan; penggandaan ciptaan dalam segala bentuk; penerjemahan ciptaan; pengadaptasian; pengaransemen atau pentrasformasian ciptaan; pendistribusian ciptaan atau salinannya; pertunjukkan ciptaan; pengumuman ciptaan; komunikasi ciptaan; dan penyewaan ciptaan. $^{22}$ Jika ada pihak yang hendak melaksanakan hak ekonomi sebagaimana dimaksud diatas maka pihak tersebut wajib mendapatkan izin dari pencipta atau izin dari pemegang hak cipta. Jika pihak tersebut

\footnotetext{
${ }^{19}$ Ibid., hlm. 2

${ }^{20}$ Ferol Mailangkay, "Kajian Hukum Tentang Hak Moral Pencipta Dan Pengguna Menurut Undang-Undang Nomor 28 Tahun 2014 Tentang Hak Cipta," Lex Privatum 5, no. 4 (2017): 138.

${ }^{21}$ Henry Soelistyo, Hak Cipta Tanpa Hak Moral (Jakarta: Rajawali Press, 2011).

${ }^{22}$ Khwarizi Maulana Simatupang, "Tinjauan Yuridis Perlindungan Hak Cipta Dalam Ranah Digital (Juridical Review of Copyright Protection in Digital Sector)," Jurnal Ilmiah Kebijakan Hukum 15, no. 1 (2021): 71.
} 
tidak mendapatkan izin dari pencipta atau pemegang hak cipta maka terjadi pelanggaran hukum hak cipta dan dapat dilakukan upaya hukum perdata dan pidana sesuai ketentuan peraturan perundang-undangan. Pasal 16 ayat 2 UU Hak Cipta mengatur bahwa hak cipta dapat dialihkan sebagian atau seluruhnya. Yang dimaksud adalah hanya hak ekonominya saja yang dialihkan, sedangkan hak moral tidak dapat dialihkan dan tetap melekat pada diri pencipta. Pengalihan hak ekonomi dilakukan secara jelas dan tertulis, serta dapat menggunakan akta notaris untuk kekuatan pembuktian yang sempurna. Pasal 16 ayat 2 UU Hak Cipta juga mengatur berbagai cara pengalihan hak ekonomi, yaitu melalui pewarisan, hibah, wakaf, wasiat, perjanjian tertulis atau sebab lain yang dibenarkan sesuai dengan ketentuan peraturan perundang-undangan.

Penjelasan Pasal 16 ayat 2 UU Hak Cipta memberikan contoh pengalihan hak ekonomi karena sebab lain yang dibenarkan sesuai dengan ketentuan peraturan perundang-undangan, yaitu antara lain pengalihan karena disebabkan oleh putusan pengadilan yang telah memperoleh kekuatan hukum tetap, merger, akuisisi, atau pembubaran perusahaan atau badan hukum dimana terjadi penggabungan atau pemisahan aset perusahaan. Selanjutya terdapat masa berlaku hak moral dan hak ekonomi. Pasal 57 UU Hak Cipta mengatur masa berlaku pelindungan hak moral pencipta dengan memisahkannya dalam dua kategori, yaitu hak moral yang masa berlakunya tanpa batas waktu dan hak moral yang masa berlakunya mengikuti masa waktu pelindungan hak ekonomi. Masa berlaku pelindungan hak moral atas ciptaan untuk mencantumkan atau tidak mencantumkan namanya pada salinan sehubungan dengan pemakaian ciptaannya untuk umum, menggunakan nama aliasnya atau samarannya, dan mempertahankan haknya dalam hal terjadi distorsi ciptaan, mutilasi ciptaan, modifikasi ciptaan, atau hal yang bersifat merugikan kehormatan diri atau reputasinya, berlaku tanpa batas waktu. Adapun masa berlaku pelindungan hak moral pencipta atas ciptaan untuk mengubah ciptaannya sesuai dengan kepatutan dalam masyarakat dan mengubah judul dan anak judul ciptaan, berlaku mengikuti jangka waktu hak cipta atas ciptaan.

Pasal 58 ayat 1 huruf d UU Hak Cipta menegaskan bahwa masa berlaku hak ekonomi terhadap lagu atau musik dengan atau tanpa teks adalah selama hidup pencipta dan terus berlangsung selama tujuh puluh tahun setelah pencipta meninggal dunia, terhitung mulai tanggal 1 Januari tahun berikutnya. Pasal 58 ayat 2 UU Hak Cipta menegaskan bahwa terhadap ciptaan yang dimiliki oleh dua orang atau lebih, maka masa berlaku hak ekonomi adalah selama hidup pencipta yang meninggal dunia paling akhir dan berlangsung selama tujuh puluh tahun sesudahnya, terhitung mulai tanggal 1 Januari tahun berikutnya. Lalu Pasal 58 ayat 3 UU Hak Cipta memberikan kejelasan bahwa terhadap ciptaan yang dimiliki oleh badan hukum maka masa berlaku hak ekonomi adalah lima puluh tahun terhitung sejak pertama kali dilakukan pengumuman atas ciptaan. Terkait dengan pengumuman ciptaan, Pasal 1 angka 11 UU Hak Cipta memberikan pengertian bahwa yang dimaksud dengan pengumuman ciptaan adalah pembacaan, penyiaran, pameran ciptaan dengan menggunakan alat 
apapun, baik elektronik atau non elektronik atau melakukan dengan cara apapun sehingga ciptaan dapat dibaca, didengar, atau dilihat orang lain.

Hak ekonomi dapat dilisensikan oleh pemegangnya kepada pihak lain. Pasal 1 angka 20 UU Hak Cipta memberikan pengertian lisensi sebagai izin tertulis yang diberikan oleh pemegang hak cipta untuk melaksanakan hak ekonomi atas ciptaan. Lisensi hak ekonomi atas ciptaan diberikan melalui perjanjian tertulis, wajib dicatatkan ke pemerintah supaya memiliki akibat hukum kepada pihak ketiga, terdapat royalti yang harus dibayarkan oleh penerima lisensi kepada pemberi lisensi, dan persyaratan lainnya yang diatur dalam UU Hak Cipta. Dengan adanya hak moral dan hak ekonomi atas ciptaan, maka pencipta dan/atau pemegang hak ekonomi dapat mempertahankan hak atas ciptaan yang dimilikinya dari pihak lain yang tmenggunakan ciptaannya secara tanpa hak. Pasal 99 ayat 1 UU Hak Cipta menegaskan bahwa pencipta dan pemegang hak cipta berhak mengajukan gugatan ganti rugi kepada pengadilan niaga atas pelanggaran hak cipta. Kemudian Pasal 95 UU Hak Cipta mengatur bahwa penyelesaian sengketa hak cipta dapat dilakukan melalui lembaga alternatif penyelesaian sengketa, arbitrase, atau pengadilan niaga. Kemudian selain pelanggaran hak cipta dalam bentuk pembajakan, sepanjang para pihak yang bersengketa berada di wilayah Indonesia, maka para pihak yang bersengketa harus menempuh mediasi sebelum menuntut pihak lain secara pidana. Selanjutnya Pasal 96 ayat 1 UU Hak Cipta mengatur bahwa pencipta dan pemegang hak cipta atau ahli warisnya yang mengalami kerugian hak ekonomi berhak memperoleh ganti rugi.

Selain gugatan perdata, UU Hak Cipta juga mengatur sanksi pidana yang deliknya adalah delik aduan, artinya pihak yang merasa hak moral dan/atau hak ekonomi atas ciptaannya dirugikan oleh pihak lain, dapat membuat laporan kepada pihak yang berwajib. Pengaturan sanksi pidana dalam UU Hak Cipta terdapat dalam Pasal 112 sampai dengan Pasal 119.

Berbagai pengaturan yang telah diuraikan diatas kemudian dikaitkan dengan ciptaan berupa jingle yang dilihat dari aspek hak moral, hak ekonomi, pengalihan hak ekonomi, masa berlaku pelindungan hak moral dan hak ekonomi, serta lisensi hak ekonomi. Mengingat bahwa hak ekonomi atas jingle dapat dialihkan ke pihak lain maka terdapat dua kemungkinan kepemilikan atas jingle. Pertama, hak moral dan hak ekonomi atas jingle dipegang oleh pihak yang sama. Kedua, hak moral dan hak ekonomi atas jingle dipegang oleh pihak yang berbeda. Hal tersebut merupakan konsekuensi logis dari diakuinya konsep pemisahan kepemilikan yang dalam sistem hukum hak cipta.

Dari aspek hak moral, pencipta jingle sebagai pemegang hak moral dan pemegang hak ekonomi atas jingle dapat melakukan hal-hal sebagai berikut:

a. mencantumkan atau tidak mencantumkan namanya pada jingle sehubungan dengan pemakaiannya untuk umum

b. menggunakan nama aliasnya atau samarannya pada jingle

c. mengubah jingle sesuai dengan kepatutan dalam masyarakat 
d. mengubah judul dan anak judul jingle

e. mempertahankan haknya dalam hal terjadi distorsi, mutilasi, modifikasi terhadap jingle atau hal yang bersifat merugikan kehormatan diri atau reputasinya

f. menggandakan jingle dalam segala bentuk, mengadaptasikan, mengaransemen atau mentransformasikan, mendistribusikan, mempertunjukkan, mengumumkan, mengkomunikasikan, dan menyewakan

Kemudian pemegang hak cipta selaku pemegang hak ekonomi atas jingle akibat pengalihan hak ekonomi atas jingle dapat menggandakan jingle dalam segala bentuk, mengadaptasikan, mengaransemen atau mentransformasikan, mendistribusikan, mempertunjukkan, mengumumkan, mengkomunikasikan, dan menyewakan. Masa berlaku pelindungan hak moral atas jingle dalam hal mencantumkan atau tidak mencantumkan nama pencipta pada salinan sehubungan dengan pemakaian jingle untuk umum, menggunakan nama alias pencipta jingle atau nama samaran, dan mempertahankan hak pencipta jingle dalam hal distorsi jingle, mutilasi jingle, modifikasi jingle, atau hal-hal yang bersifat merugikan kehormatan diri atau reputasi pencipta jingle adalah berlaku terus tanpa batas waktu. Adapun masa berlaku pelindungan hak moral pencipta atas jingle dalam hal mengubah jingle sesuai dengan kepatutan dalam masyarakat, mengubah judul jingle dan anak judul jingle mengikuti jangka waktu pelindungan hak ekonomi jingle.

Masa berlaku hak ekonomi terhadap jingle tergantung dari beberapa hal, yaitu sebagai berikut:

a. jika jingle dimiliki oleh satu orang maka hak ekonomi berlaku seumur hidup pemegang hak ekonomi dan terus berlangsung untuk tujuh puluh tahun setelah pemegang hak ekonomi meninggal dunia, terhitung mulai tanggal 1 Januari tahun berikutnya

b. jika jingle dimiliki oleh dua orang atau lebih maka hak ekonomi berlaku seumur hidup pemegang hak ekonomi yang meninggal dunia paling akhir dan berlangsung selama tujuh puluh tahun sesudahnya, terhitung mulai tanggal 1 Januari tahun berikutnya

c. jika jingle dimiliki oleh badan hukum masa berlaku hak ekonomi adalah lima puluh tahun terhitung sejak pertama kali dilakukan pengumuman jingle

Hak ekonomi atas jingle dapat dilisensikan kepada pihak lain berdasarkan perjanjian tertulis dan terdapat royalti yang harus dibayarkan oleh penerima lisensi jingle kepada pemberi lisensi jingle. Perjanjian lisensi jingle wajib dicatatkan di pemerintah supaya berakibat hukum kepada pihak ketiga. Lalu pencipta dan/atau pemegang hak cipta atas jingle dapat mempertahankan haknya secara perdata dan pidana dalam hal jingle dipergunakan oleh pihak lain yang tidak berhak.

Dalam UU Hak Cipta, tidak terdapat pengaturan yang melarang jingle sebagai objek hak cipta untuk didaftarkan sebagai merek suara maupuan sebaliknya. UU Hak Cipta pada Pasal 65 hanya mengatur mengenai pencatatan ciptaan tidak dapat dilakukan terhadap seni lukis yang berupa logo atau tanda pembeda yang digunakan 
sebagai merek dalam perdagangan barang dan/atau jasa atau digunakan sebagai lambang organisasi, badan usaha, atau badan hukum. Dengan demikian, jingle sebagai objek ciptaan, baik yang tidak tercatat maupun yang telah tercatat, dapat didaftarkan sebagai merek suara. Pada praktiknya di Indonesia saat ini sudah ada jingle yang lebih dulu dicatatkan hak ciptanya dan kemudian didaftarkan sebagai merek suara. Jingle tersebut adalah adalah jingle milik PT. Matahari Departement Store, Tbk., pencatatan hak cipta nomor $000104733^{23}$ dan merek suara terdaftar nomor IDM000763062. ${ }^{24}$

Namun penting untuk diperhatikan bahwa terhadap jingle yang pemegang hak moralnya dan pemegang hak ekonominya dipegang oleh pihak yang berbeda, maka dalam mendaftarkan jingle sebagai merek suara tidak boleh merugikan serta tidak boleh meniadakan keberadaan pemegang hak moral. Pemegang hak moral harus tetap dihormati dan diakomodasi. Hal ini penting untuk dicermati dan diingat karena dalam sistem hukum merek tidak mengenal pemisahan hak moral dan hak ekonomi.

Manfaat jingle sebagai ciptaan tentu mendatangkan manfaat ekonomi melalui komersialisasi lagu atau musik jingle dalam berbagai kegiatan. Kepemilikan hak ekonomi atas jingle juga dapat diperjualbelikan oleh pemegang hak cipta kepada pihak lain. Dalam hal jingle telah dicatatkan di DJKI maka juga mendapat manfaat ekstra dari sisi administratif, dimana data pencatatan jingle dapat digunakan oleh pemegang hak moral dan pemegang hak ekonomi jika jingle digunakan secara tanpa hak oleh pihak yang tidak bertanggung jawab.

\section{Pengaturan Hak Atas Merek Dalam Undang-Undang Merek dan Indikasi Geografis Yang Terkait Dengan Jingle}

Telah diuraikan dalam bagian latar belakang bahwa jingle masuk dalam kategori merek suara. Kemudian dalam Pasal 2 ayat 2 UU Merek dan IG terdapat kategori merek, yaitu merek dagang dan merek jasa. Adapun sistem hukum merek menganut prinsip konstitutif dimana untuk mendapatkan pelindungan hukum merek maka sebuah merek haruslah terdaftar terlebih dahulu. Hal pendaftaran merek diatur dengan jelas pada Pasal 3 UU Merek dan IG yang menyatakan bahwa hak atas merek diperoleh setelah merek tersebut terdaftar. Dengan terdaftarnya merek maka timbul hak eksklusif yang disebut dengan hak atas merek. Tujuan pemberian hak eksklusif atas merek agar mempermudahkan pemberian jaminan perlindungan hukum kepada pemilik merek tersebut. $^{25}$

\footnotetext{
${ }^{23}$ Pangkalan Data Kekayaan Intelektual Direktorat Jenderal Kekayaan Intelektual Kementerian Hukum \& HAM RI, "Hak Cipta - Matahari Jingle End Tune," 2017, https://pdkiindonesia.dgip.go.id/detail/EC00201808361?type=copyright\&keyword=jingle+ matahari+department+store.

${ }^{24}$ Pangkalan Data Kekayaan Intelektual Direktorat Jenderal Kekayaan Intelektual Kementerian Hukum \& HAM RI, "Merek - Jingle Matahari $+\quad$ Logo," $2018, \quad \mathrm{https} / / \mathrm{pdki}$ indonesia.dgip.go.id/detail/J002018009556?type=trademark\&keyword=jingle+matahari .

${ }^{25}$ Nanda Salsabilla Latukau, "Perlindungan Hukum Merek Produk Jus Pala Di Negeri Morella Kecamatan Leihitu," Jurnal Ilmu Hukum Tatohi 1, no. 5 (2021): 418.
} 
Hak yang dimiliki oleh subyek hukum atas merek disebut sebagai hak atas merek. Pasal 1 angka 5 UU Merek dan IG mengartikan hak atas merek sebagai hak eksklusif yang diberikan oleh negara kepada pemilik merek yang terdaftar untuk jangka waktu tertentu dengan menggunakan sendiri merek tersebut atau memberikan izin kepada pihak lain untuk menggunakannya. Berdasarkan ketentuan pasal tersebut maka hak eksklusif atas merek menimbulkan dua macam hak, yaitu hak bagi pemilik merek untuk menggunakan merek yang dimilikinya sendiri dalam kegiatan perdagangan barang dan/atau jasa dan hak bagi pemilik merek untuk memberikan izin kepada pihak lain untuk menggunakan merek dalam waktu tertentu dan dengan biaya tertentu.

Pasal 2 ayat 3 UU Merek dan IG memberikan penegasan bahwa merek yang diberikan pelindungan hukum adalah merek yang terdiri atas tanda berupa gambar, logo, nama, kata, huruf, angka, susunan warna, dalam bentuk dua dimensi dan/atau tiga dimensi, suara, hologram, atau kombinasi dari dua atau lebih unsur tersebut untuk membedakan barang dan/atau jasa yang diproduksi oleh orang atau badan hukum dalam kegiatan perdagangan barang dan/atau jasa. Dengan demikian jingle sebagai tipe merek suara merupakan merek yang dapat didaftarkan.

Hak atas merek terdaftar memiliki jangka waktu pelindungan hukum. Pasal 35 ayat 1 UU Merek dan IG mengatur bahwa merek terdaftar mendapat pelindungan hukum selama sepuluh tahun terhitung sejak tanggal penerimaan permohonan pendaftaran merek. Kemudian Pasal 35 ayat 2 UU Merek dan IG mengatur bahwa jangka waktu pelindungan hukum terhadap hak atas merek terdaftar dapat diperpanjang setiap kelipatan sepuluh tahun. Perpanjangan jangka waktu pelindungan hukum hak atas merek terdaftar tidak secara otomatis melainkan berdasarkan permohonan dari pemilik hak atas merek tersebut.

Sebagai benda bergerak dan tidak berwujud, hak atas merek terdaftar dapat dialihkan kepemilikannya kepada pihak lain. Pasal 41 ayat 1 UU Merek dan IG mengatur bahwa pengalihan hak atas merek terdaftar dapat dilakukan melalui berbagai cara, yaitu warisan, wasiat, wakaf, hibah, perjanjian, atau oleh sebab lain yang dibenarkan oleh peraturan perundang-undangan. Penjelasan Pasal 41 ayat 1 huruf $\mathrm{f}$ UU Merek dan IG memberikan pembatasan bahwa yang dimaksud dengan sebab lain yang dibenarkan oleh peraturan perundang-undangan adalah sepanjang tidak bertentangan dengan peraturan perundang-undangan, yaitu misalnya perubahan kepemilikan merek karena pembubaran badan hukum, restrukturisasi, penggabungan, atau akuisisi. Pengalihan hak atas merek terdaftar dari satu pihak ke pihak lainnya wajib dicatatkan ke pemerintah melalui supaya memiliki akibat hukum kepada pihak ketiga.

Seperti yang telah diuraikan bahwa pemilik hak atas merek terdaftar dapat memberikan izin kepada pihak lain untuk menggunakan mereknya. Hal tersebut disebut dengan lisensi. Pasal 1 angka 18 UU Merek dan IG memberikan definisi lisensi sebagai izin yang diberikan pemilik merek terdaftar kepada pihak lain berdasarkan perjanjian secara tertulis sesuai peraturan perundang-undangan untuk 
rnenggunakan merek terdaftar. Pasal 42 ayat 6 UU Merek dan IG menegaskan bahwa isi perjanjian lisensi merek dilarang memuat ketentuan baik yang langsung maupun tidak langsung yang menimbulkan akibat yang merugikan perekonomian Indonesia atau memuat pembatasan yang menghambat kemampuan bangsa Indonesia dalam menguasai dan mengembangkan teknologi. Perjanjian lisensi wajib dicatatkan agar memiliki kekuatan hukum bagi pihak ketiga.

Kemudian pemilik merek terdaftar dan/atau pemegang lisensi merek terdaftar dapat mempertahankan hak atas merek terhadap pihak lain yang secara tanpa hak menggunakan merek yang mempunyai persamaan pada pokoknya atau keseluruhannya untuk barang dan/atau jasa yang sejenis. Pasal 83 ayat 1 UU Merek dan IG mengatur cara mempertahankan hak atas merek terdaftar dengan cara melayangkan gugatan ganti rugi kepada pihak yang secara tanpa hak menggunakan mereknya dan/atau penghentian semua perbuatan yang berkaitan dengan penggunaan merek. Gugatan dilayangkan melalui pengadilan niaga.

Pasal 184 ayat 1 UU Merek dan IG juga memberikan pengaturan bahwa selama gugatan pelanggaran merek masih dalam pemeriksaan maka untuk mencegah kerugian yang lebih besar, pemilik merek terdaftar dan/atau penerima lisensi merek, maka pemilik merek terdaftar selaku penggugat dapat mengajukan permohonan kepada hakim pengadilan niaga untuk memerintahkan kepada tergugat agar menghentikan kegiatan produksi, peredaran, dan/atau perdagangan barang dan/atau jasa yang menggunakan merek tersebut. Adapun Pasal 184 ayat 2 UU Merek dan IG mengatur bahwa dalam hal tergugat dituntut untuk menyerahkan barang yang diperdagangkan dengan menggunakan merek penggugat, maka hakim dapat memerintahkan tergugat untuk menyerahkan fisik barang atau sejumlah nilai tertentu berdasarkan nilai barang, namun hal dilaksanakan oleh tergugat setelah putusan pengadilan mempunyai kekuatan hukum tetap. Selanjutnya terdapat ancaman sanksi pidana terhadap subjek hukum yang terbukti menggunakan merek yang sama pada keseluruhannya dengan merek terdaftar milik pihak lain. Sanksi pidana tersebut berupa pidana penjara, pidana kurungan dan pidana denda. Kemudian penting untuk diperhatikan bahwa delik pidana dalam sistem hukum merek adalah adalah delik aduan, artinya pihak yang merasa dirugikan harus berinisiatif melapor kepada pihak yang berwenang.

Pasal 100 ayat 1 UU Merek dan IG menegaskan bahwa setiap orang (subjek hukum) yang dengan tanpa hak menggunakan merek yang sama pada keseluruhannya dengan merek terdaftar milik pihak lain untuk barang dan/atau jasa sejenis yang diproduksi dan/atau diperdagangkan, dipidana dengan pidana penjara paling lama 5 tahun dan/atau pidana denda paling banyak dua miliar rupiah. Pasal 100 ayat 2 UU Merek dan IG, setiap orang (subjek hukum) yang dengan tanpa hak rnenggunakan merek yang mempunyai persamaan pada pokoknya dengan merek terdaftar milik pihak lain untuk barang dan/atau jasa sejenis yang diproduksi dan/atau diperdagangkan, dipidana dengan pidana penjara paling lama 4 tahun dan/atau denda paling banyak dua miliar rupiah. Lalu Pasal 102 UU Merek dan IG mengatur bahwa 
setiap orang (subjek hukum) yang memperdagangkan barang dan/atau jasa dan/atau produk yang diketahui atau patut diduga sudah mengetahui bahwa barang dan/atau jasa dan/atau produk tersebut merupakan hasil tindak pidana sebagaimana dimaksud dalam Pasal 100 dipidana dengan pidana kurungan paling lama 1 tahun atau denda paling banyak dua ratus juta rupiah.

Selain upaya hukum melalui pengadilan niaga, UU Merek dan IG memberikan pilihan melalu jalur lain. Pasal 93 UU Merek dan IG menegaskan bahwa penyelesaian sengketa merek dapat melalui lembaga arbitrase atau lembaga alternatif penyelesaian sengketa. Namun hal tersebut harus disepakati oleh seluruh pihak yang bersengketa. Berbagai pengaturan mengenai hak eksklusif berupa hak atas merek terdaftar yang diuraikan diatas kemudian dikaitkan dengan jingle sebagai merek suara yang telah terdaftar. Pemilik merek suara terdaftar berbentuk jingle dapat menggunakan jingle secara langsung atau melisensikannya kepada pihak lain. Adapun jangka waktu pelindungan hukum merek suara berbentuk jingle adalah sepuluh tahun dan dapat diperpanjang berdasarkan permohonan perpanjangan dari pemiliknya.

Kemudian hak atas merek suara berbentuk jingle dapat dialihkan oleh pemiliknya melalui warisan, wasiat, wakaf, hibah, perjanjian, atau oleh sebab lain yang dibenarkan oleh peraturan perundang-undangan seperti pembubaran badan hukum, restrukturisasi, penggabungan, atau akuisisi. Pengalihan hak atas merek suara berbentuk jingle wajib dicatatkan ke pemerintah supaya memiliki akibat hukum kepada pihak ketiga. Pemilik hak atas merek berbentuk jingle dapat melisensikan jingle yang dimilikinya kepada pihak lain dengan menggunakan perjanjian tertulis dan dicatatkan di pemerintah supaya mempunyai akibat hukum kepada pihak ketiga. Lalu pemilik jingle yang telah terdaftar sebagai merek suara dan pemegang lisensi jingle dapat mempertahankan haknya jika jingle digunakan oleh pihak lain secara tanpa hak. Pemilik merek dapat melayangkan gugatan ke pengadilan niaga atau ke lembaga arbitrase atau ke lembaga alternatif penyelesaian sengketa. Di samping itu juga terdapat sanksi pidana terhadap pihak lain yang terbukti secara tanpa hak menggunakan jingle yang memiliki persamaan pada pokoknya atau keseluruhannya terhadap jingle yang telah terdaftar sebagai merek.

Dalam UU Merek dan IG tidak terdapat pengaturan yang melarang jingle yang sudah terdaftar sebagai merek suara di DJKI kemudian dicatatkan sebagai hak cipta ataupun sebaliknya. Berdasarkan hal tersebut maka tidak terdapat pembatasan terhadap jingle yang telah terdaftar sebagai merek suara, kemudian mendapatkan pelindungan hak cipta serta mencatatkan hak cipta atas jingle. Terhadap jingle yang telah terdaftar sebagai merek suara, manfaat yang didapatkan oleh pemiliknya adalah terdapatnya pelindungan hukum atas merek sehingga dapat menggunakan jingle dalam kegiatan perdagangan barang dan/atau jasa, baik melalui periklanan maupun diperdengarkan di berbagai tempat dengan aman. Jika ada pihak lain yang menggunakan jingle tersebut secara tanpa hak, maka pemilik hak atas merek suara jingle dapat mempertahankan haknya dengan cara memberikan teguran tertulis sampai dengan melakukan gugatan hukum perdata maupun pidana. 


\section{KESIMPULAN}

Dari sisi hukum hak cipta, hak eksklusif atas jingle timbul otomatis setelah jingle selesai dibuat. Hak eksklusif atas jingle terdiri dari 2 bentuk, yaitu hak moral dan hak ekonomi. Hak moral atas jingle tidak dapat dialihkan kepada pihak lain, namun hak ekonomi atas jingle dapat dialihkan kepada pihak lain. Dengan demikian pencipta jingle dapat sebagai pemegang hak moral dan pemegang hak ekonomi atau pencipta jingle dan pemegang hak ekonomi atas jingle merupakan pihak yang berbeda. Pemegang hak moral atas jingle memiliki hak untuk mengawasi penggunaannya dengan maksud supaya jingle digunakan sesuai dengan bentuknya sebagai ciptaan yang berbentuk musik atau lagu. Pemegang hak cipta memiliki hak untuk menikmati manfaat ekonomi atas penggunaan jingle melalui berbagai cara yang diatur dalam UU Hak Cipta.

Dari sisi merek, hak eksklusif berupa hak atas merek suara berupa jingle timbul berdasarkan permohonan pendaftaran merek. Jika permohonan pendaftaran jingle dikabulkan dan jingle menjadi merek terdaftar, maka jingle terproteksi sebagai merek dan memberikan hak kepada pemiliknya untuk menggunakan dalam kegiatan pemasaran dan periklanan atas barang dan/atau jasa dan melarang pihak lain yang tidak berhak menggunakan jingle yang dimilikinya. Perlindungan hukum hak atas merek diberikan untuk 10 tahun dan dapat diperpanjang setiap kelipatan 10 tahun berikutnya berdasarkan permohonan. Pemilik merek suara berupa jingle dapat mengalihkan haknya kepada pihak lain melalui berbagai cara yang diatur dalam UU Merek dan IG. Pemegang hak merek terdaftar jingle juga berhak untuk mempertahakan haknya dalam hal jingle dipergunakan oleh pihak lain yang tidak berhak, upaya hukum yang dapat dilakukan adalah secara perdata dan/atau pidana.

Akibat yang ditimbulkan dari pelindungan ganda hak cipta dan merek terhadap jingle adalah pemegang hak moral atas jingle, pemegang hak ekonomi atas jingle, dan pemegang hak atas merek suara berbentuk jingle dapat mengeksploitasi jingle yang dimilikinya dan mempertahankan haknya terhadap pihak lain yang menggunakan jingle secara tanpa hak. Hal tersebut dapat dikatakan sebagai manfaat ganda dari jingle. Dalam sistem hukum merek perlu mengakomodasi jingle yang pemegang hak moral dan pemegang hak ekonominya pihak yang berbeda. Hal tersebut diperlukan supaya dengan adanya pelindungan hukum ganda dalam bentuk hak cipta dan merek terhadap jingle jangan sampai menimbulkan masalah dari aspek kepemilikannya.

Pemerintah, akademisi, dan praktisi hak kekayaan intelektual perlu melakukan kajian ilmiah secara menyeluruh dan mendalam terhadap UU Hak Cipta dan UU Merek dan IG yang memiliki keterkaitan terhadap jingle, utamanya terhadap jingle sebagai merek suara yang pencipta (pemegang hak moral) dan pemegang hak cipta (pemegang hak ekonomi) adalah pihak yang berbeda. Para pihak tersebut juga perlu meneliti implementasi pelindungan ganda jingle di masyarakat saat ini. Penghargaan atas pembuat jingle tentunya harus diakui karena pembuat jingle mempunyai peran penting dalam eksistensi merek dagang atau jasa. Selain itu seluruh pemangku kepentingan perlu bekerjasama mengadakan sosialisasi berkala kepada masyarakat mengenai adanya 
pelindungan hukum hak cipta dan merek terhadap jingle, hal tersebut diperlukan supaya pihak-pihak yang memiliki jingle namun belum mengetahui adanya pelindungan ganda terhadap jingle dapat mengetahuinya dan dapat mencatatkan hak cipta atas jingle dan mendaftarkan merek suara atas jingle. Sosialisasi berkala tersebut dapat dilakukan secara daring maupun luring.

\section{DAFTAR PUSTAKA}

\section{Buku}

Jened, Rahmi. Hukum Merek (Trademark Law) Dalam Era Globalisasi Dan Integrasi Ekonomi. Pertama. Jakarta: Kencana, 2015.

Mayana, Ranti Fauza; Santika Tisni. Hukum Merek Perkembangan Aktual Perlindungan Merek Dalam Konteks Ekonomi Kreatif Di Era Disrupsi Digital. Bandung: Refika Aditama, 2021.

Soelistyo, Henry. Badfaith Dalam Hukum Merek. Yogyakarta: Maharsa, 2016.

. Hak Cipta Tanpa Hak Moral. Jakarta: Rajawali Press, 2011.

Susanti, R. Diah Imaningrum. Hak Cipta Kajian Filosofis Dan Historis, 2017.

Tim Visi Yustisia. Panduan Resmi Hak Cipta Dari Mendaftar, Melindungi, Hingga Menyelesaikan Sengketa, 2015.

\section{Jurnal}

Dewi, Ni Putu Wanda Pramesti. "Pendaftaran Suara Sebagai Merek Non Tradisional Berdasarkan Undang-Undang No. 20 Tahun 2016 Tentang Merek.” Ilmu Hukum 7, no. 10 (2019): 3.

Latukau, Nanda Salsabilla. "Perlindungan Hukum Merek Produk Jus Pala Di Negeri Morella Kecamatan Leihitu." Jurnal Ilmu Hukum Tatohi 1, no. 5 (2021): 418.

Loebis, Roma Ayuni A. "Lagu, Kaum Muda Dan Budaya Demokrasi." Pustaka 8, no. 2 (2018): 82.

Khoiriyah, Niswati dan Sinaga, Syahrul Syah. "Pemanfaatan Pemutaran Musik Terhadap Psikologis Pasien Pada Klinik Ellena Skin Care Di Kota Surakarta.” Jurlan Seni Musik 6, no. 2 (2017): 82.

Megahayati, Kemala. Amirulloh, Muhammad. dan Muchtar, Helitha Novianty. "Perlindungan Hukum Sinematografi Terhadap Pengaksesan Tanpa Hak Oleh Pengguna Aplikasi Telegram Berdasarkan Undang-Undang Hak Cipta Dan Undang-Undang Informasi Dan Transaksi Elektronik Di Indonesia." Ajudikasi: Jurnal Ilmu Hukum 5, no. 1 (2021): 5.

Mailangkay, Ferol. "Kajian Hukum Tentang Hak Moral Pencipta Dan Pengguna Menurut Undang-Undang Nomor 28 Tahun 2014 Tentang Hak Cipta." Lex Privatum 5, no. 4 (2017): 138.

Nurdahniar, Inda. “Analisis Penerapan Prinsip Perlindungan Langsung Dalam Penyelenggaraan Pencatatan Ciptaan.” Veritas Et Justitia 2, no. 1 (2016): 233-34

Simatupang, Khwarizi Maulana. "Tinjauan Yuridis Perlindungan Hak Cipta Dalam Ranah 
Digital (Juridical Review of Copyright Protection in Digital Sector)." Jurnal Ilmiah Kebijakan Hukum 15, no. 1 (2021): 71.

\section{Makalah Seminar}

Nasir, Moech. "Analisis Pengaruh Bintang Iklan Dan Jingle Iklan Terhadap Daya Ingat Konsumen Produk "Vaseline Men"." In Prosiding Seminar Nasional Ekonomi Dan Bisnis \& Call for Paper FEB UMSIDA. Surakarta, 2016

\section{Tesis}

Pratidina, Mozza. "Konsepsi Dan Implementasi Perlindungan Hukum Bagi Jingle Sebagai Merek Nontradisional Suara." Universitas Pelita Harapan, 2020.

Rahman, Rajulur. "Suara Sebagai Merek Yang Dilindungi Berdasarkan Undang-Undang Nomor 20 Tahun 2016 Tentang Merek Dan Indikasi Geografis." Universitas Indonesia, 2018.

\section{Peraturan Perundang-Undangan}

Undang-Undang Nomor 28 Tahun 2014 tentang Hak Cipta.

Undang-Undang Nomor 20 Tahun 2016 tentang Merek dan Indikasi Geografis.

\section{Internet}

Pangkalan Data Kekayaan Intelektual Direktorat Jenderal Kekayaan Intelektual Kementerian Hukum \& HAM RI. "Hak Cipta - Matahari Jingle End Tune," 2017. https://pdkiindonesia.dgip.go.id/detail/EC00201808361?type=copyright\&keyword=jingle+ matahari+department+store.

- "Merek - Jingle Matahari + Logo," 2018. https://pdkiindonesia.dgip.go.id/detail/J002018009556?type=trademark\&keyword=jingle+matahari. 